\title{
Titanium isotopic compositions of bulk rocks and mineral separates from the Kos magmatic suite: Insights into fractional crystallization and magma mixing processes
}

\author{
DR. NICOLAS DAVID GREBER ${ }^{1}$, DR. THOMAS PETTKE ${ }^{1}$, \\ NICOLAS VILELA ${ }^{1}$, PIERRE LANARI ${ }^{1}$ AND NICOLAS \\ DAUPHAS $^{2}$ \\ ${ }^{1}$ University of Bern \\ ${ }^{2}$ The University of Chicago \\ Presenting Author: greber@geo.unibe.ch
}

The isotopic composition of $\mathrm{Ti}$ in terrestrial and extraterrestrial rocks exhibits significant mass-dependent variations, with basalts being isotopically lighter than evolved lithologies [1]. The observed shift from light to heavy Ti isotopes from more primitive to more differentiated rocks agrees with theoretical predictions that light $\mathrm{Ti}$ isotopes are sequestered in $\mathrm{Fe}-\mathrm{Ti}$ oxides. However, there are lingering questions about the exact extent of this fractionation and whether it is influenced by the nature of the oxides and the nature of the silicate melt. To improve on this matter, we report $\mathrm{Ti}$ isotopic compositions of mineral separates and bulk rocks from the calc-alkaline Kos volcano-plutonic system, Aegean arc, Greece. Bulk rock Ti isotopic compositions $\left(\delta^{49} \mathrm{Ti}\right)$ increase with progressive fractionation of the magmatic system, from $\delta^{49} \mathrm{Ti}$ of around $+0.04 \%$ in a basalt to $+0.65 \%$ in a rhyolite. However, when comparing $\mathrm{Ti}$ isotopes with indices of magmatic differentiation, we observe two different trends, one that can be explained by fractional crystallization, and another that results from mixing between a basaltic melt and an evolved (rhyolitic) magma.

The mineral separates reveal variable $\delta^{49} \mathrm{Ti}$ values, with magnetite having the lightest $\mathrm{Ti}$ isotopic composition, biotite being intermediate and neso- and tectosilicates (i.e., olivine, plagioclase and quartz) heaviest. The difference in $\delta^{49} \mathrm{Ti}$ between different minerals is smallest in a basalt and largest in two rhyolites. Our data are therefore in agreement with theoretical predictions that $\mathrm{Fe}-\mathrm{Ti}$ oxides have a light $\delta^{49} \mathrm{Ti}$ signature, and neso-/tectosilicate minerals are heavy [2]. Furthermore, the measured difference in $\delta^{49} \mathrm{Ti}$ between magnetite-olivine and magnetite-quartz agree to a first order with theoretically predicted inter-mineral $\mathrm{Ti}$ isotope fractionation factors, thus suggesting that the here measured inter-mineral $\mathrm{Ti}$ isotope variations are likely dominated by equilibrium isotopic fractionation.

References:

[1] Johnson et al., 2019. Geochim. Cosmochim. Acta 264, 180-190.

[2] Millet et al., 2016. Earth Planet. Sci. Lett. 449, 197-205. 